4. Олійник С. Побутування фантастичного у сучасній українській прозі. Синопсис: текст, контекст, медіа. 2013. № 3-4. URL: http://nbuv.gov.ua/UJRN/stkm_2013_3-4_8

5. Романенко О. «Танго смерті» Ю. Винничука: масова чи висока література? Spheres of Culture. Volume V - VI. Lublin, 2013. C. 150-160.

DOI https://doi.org/10.30525/978-9934-26-110-7-15

\title{
ТИПИ ІНТОНАЦІЙ ПЕРСОНАЖІВ В ІСТОРИЧНИХ РОМАНАХ П. КРАЛЮКА («ШЕСТИДНЕВ, АБО КОРОНА РОДУ ОСТРОЗЬКОГО», «СИЛЬНІ ТА ОДИНОКІ»)
}

\author{
Мізінкіна О. О. \\ кандидат філологічних наук, \\ доиент кафедри загального та слов 'янського літературознавства \\ Одеський національний університет імені I. І. Мечникова \\ Чмир А. В. \\ учитель украӥнської мови та літератури \\ Одеська загальноосвітня школа № 56 I-III ступенів \\ Одеської міської ради Одеської області \\ м. Одеса, Україна
}

Питанням інтонації в основному займались лінгвісти (Віра Білошапкова, Олена Бризгунова та ін. «Сучасна російська мова»; Гульфія Давлєткулова «Поняття інтонації у лінгвістичній і методичній літературах»; Наталія Калиниченко «Інтонація як засіб виразності в озвучуваному художньому тексті»; Гінтаутас Кундротас, Алексас Бружас «Інтонація в художньому тексті: література постмодерна (Ю. Іванаускайте «Фортеця сплячих метеликів», В. Сорокін «Бенкет»)»; Емма Нушикян «Типологія інтонації емоційного мовлення»; Людмила Путіліна «Авторські засоби вираження інтонації у французькому художньому тексті»; Наталія Свєтозарова «Інтонація в художньому тексті»). 3-поміж літературознавців значення інтонації персонажів у художньому творі вивчали Людмила Польшикова («Інтонація як проблема поетики»), Андрій Єсін («Принципи і прийоми аналізу літературного твору») та ін. На важливості інтонації як засобу, який здатен впливати на розуміння адресата, наголошує Надія Гаврилюк: 
«Інтонація не тільки окреслює наше ставлення до сказаного (розповідна, оклична), спонукає до діалогу (питальна), а й може виокремлювати 3 повідомлення важливе слово (рему), унаслідок чого одне й те саме повідомлення матиме різний сенс» $[1$, с. 50]. Завдяки інтонації автор скеровує увагу читача на певних інтенціях персонажів. Інтонування висловлювання останніх $є$ засобом розкриття їхнього внутрішнього світу, адже інтонація емоційно насичена та виступає непрямою формою психологізму. Водночас під час читання вона допомагає зорієнтуватися реципієнтові, виділяючись у творі формою та поглиблюючи його зміст.

Сучасний майстер слова Петро Кралюк $\epsilon$ автором численних історичних повістей та романів. У великій прозі письменника привертає увагу інтонування мовлення персонажів у романах «Шестиднев, або Корона роду Острозького» (2010) і «Сильні та одинокі» (2011). У «Шестидневі» розповідається про ключові події української історії XVI ст., які репрезентовані крізь призму свідомості головного героя - князя Василя-Костянтина Острозького (1526-1608). Бажаючи увіковічити себе, цей можновладець замовляє в художника Івана свій портрет та одночасно розказує йому про минуле життя.

Розмовляючи 3 Іваном, Василь-Костянтин згадує подробиці одруження своєї племінниці Гальшки. Коли шлюб між нею та князем Дмитро Сангушком був укладений, головний герой за допомогою інтонації підкреслює, що польський король Сигізмунд II Август і мати нареченої Беата Костелецька не зможуть його розірвати: «Нічого не зроблять вони. Ні-чо-го! Хіба можна перемінити те, щзо скріплено перед лицем Господа?!» [3, с. 37]. У такий спосіб завдяки інтонуванню (поділу слова на склади) Острозький наголошує на тому, що він досяг своєї мети, організувавши вигідне одруження. Водночас вороги князя (король та мати Гальшки) не здатні йому завадити.

Ще один приклад такого типу інтонації знаходимо в розповіді Василя-Костянтина про Северина Наливайка. Полоненого козацького ватажка поляки ведуть на страту: «Кат звільняє руки Семерія від пут. Той розправляє їх - наче птах. Ось він зараз полетить - далеко, на свою Волинь, Подолію, Украйну, Дике поле. По-гу-ля-є!» [3, с. 239]. Автор роману через порівняння персонажа 3 птахом підкреслює волелюбну козацьку вдачу Северина, який навіть перед смертю цінує свободу. Емоційне забарвлення висловлювання князя допомагає творити образ Наливайка як незламного героя. Спостерігаючи за останніми хвилинами бунтівника, Острозький зазначає, що «Семерій роздивляється навколо ніби когось шукає. Хочеться крикнути: "Се-ме-рі-ю-ю-ю!»» [3, с.239]. Намагання головного героя оформити своє звертання у формі вигуку 3 
вищим тональним рівнем свідчить про те, що він справді вболівав за долю свого вихованця і хотів підтримати його перед загибеллю.

У романах П. Кралюка спостерігається ще один тип інтонування мовлення персонажів - вигуки, які характеризують ситуації. У «Шестидневі» маляр Іван згадує епізод, коли під час богослужіння до церкви вдерлися гайдуки луцького старости Олександра Семашка, щоб напасти на владику Кирила Терлецького. Художник розповідає, що в храмі «музики вдарили в струни. Гайдуки пустилися в присядки. А дівки крутяться біля них, як дзиги. Гей-гой, тра-ля-ля... Душа гуляй без кунтуша» [3, с. 142]. Висловлювання Івана передає веселу та водночас богохульну атмосферу в церкві під час нападу слуг Семашка.

Інший емоційний вигук знаходимо в «Сильних та одиноких». Це роман, присвячений діяльності Організації українських націоналістів, зокрема іiї лідера Степана Бандери. Оповідач описує бунтарство цього політичного діяча. Степан цілеспрямовано співає, порушуючи порядок («До нього підходив поліиіянт і лагідно бештав: ай-я-яй, Стефранку, не личить пане академіку так непристойно чинити, вечір бо вже, майже ніч, люди до спочинку відходять» [2, с. 35]). Відтворення звуків, які зазвичай використовуються для присоромлення дітей, вказує на те, що він добродушно засуджує таку поведінку Бандери.

Звуконаслідувальні слова представляють ще один тип інтонації. У «Шестидневі» $\epsilon$ епізод, в якому розповідається про перебування Северина Наливайка в польській в'язниці. Козацький ватажок описує Острозькому свої муки: «Не дають спати. Поставили чоловіка з билом. Тільки замкну очі, а він тим билом б' $\epsilon$ - бам-бам-бам. Це бамкання $i$ зараз у голові. Так день за днем. Думав: збожеволію. < .. > Стояли в мене круги вогненні перед очима. Плила земля. I небо. I все навколо. Здавалось: перемішались вони. I я теж кручуся в цій круговерті. А те бам-бам-бам підкидає мене - високо-високо. Я падаю $і$ б'юся об землю. Хай би сили дала мати-землиия - як давала колись. Та не дає. Чужою мені стала» [3, с. 237-238]. Северин завдяки передачі звуків музичного ударного інструменту розповідає про свій важкий психологічний стан. Вимушене слухання звуку била спричиняє в персонажа зорові та відчуттєві галюцинації.

Продовжувачем Наливайка в боротьбі за українську волю став Степан Бандера. Тому в романі «Сильні та одинокі» П. Кралюк невипадково проводить паралелі між вищевказаним лідером ОУН та Северином. Слідчий «механічно ставить запитання. Степан так само механічно відповідає: не знаю, не чув, не робив. Минає година, друга, третя. Валігурський нервово тарабанить пальиями по столу. І ці звуки - 
як удари молоточком по голові. Тук-тук-тук... Степан буде триматися. Колись Наливайко тут, у Варшаві, в тюрмі, теж тримався. I йому так само не давали спати» [2, с. 29]. Звуконаслідувальний трикратний повтор однакових складів (тук-тук-тук) деякою мірою схожий на попередній (бам-бам-бам). Це дає підстави говорити про те, що межовий стан психічного напруження Степана подібний до того, що переживав Северин.

Показовою є бунтівна поведінка Бандери, коли він ще був студентом. Зустрівши поліцейського, лідер ОУН не боїться 3 ним жартувати: «Степан починає гавкати, як старий здоровенний собачюра - голосно, розмірено: гаф-гаф-гаф... Поліціянт махає руками. Студент ніби зважає на те. I дзявкає, як маленький песик» [2, с. 36]. Повторення однотипних складів на відтворення звуків собаки свідчить про те, що в Бандери відсутнє схиляння перед органами влади. Лідер ОУН перед поліцейським продовжує грати далі: ««M-я-я-у-y...»- покірно, по-котячому завершує свою епопею Степан. I чемно вклоняється, яко артист перед публікою, покидаючи сцену» [2, с. 36]. Імітація Бандерою звуків кота вказує на його психологічну перевагу і невизнання будь-яких авторитетів.

Отже, у «Шестидневі» і «Сильних та одиноких» інтонування мовлення персонажів відіграє велику роль у поворотних ситуаціях. У розглянутих уривках романів спостережено типи інтонації із залученням поділу слів на склади, відтворюванням вигуків та звуконаслідувальних слів. Інтонація слугує для акцентування певних слів або речень, які психологічно поглиблюють та увиразнюють сенс повідомлюваного. Таке мовлення є не тільки елементом комунікації, а й засобом емоційного вираження до сказаного персонажами. Інтонація допомагає індивідуалізувати останніх, наголосити героям на важливих моментах та виразити своє суб'єктивне ставлення.

\section{Література:}

1. Гаврилюк Н. Візуальний образ як текст. Слово $i$ час. 2015. № 4. С. 49-57.

2. Кралюк П. Сильні та одинокі : роман. Київ : Ярославів Вал, 2011. $280 \mathrm{c}$.

3. Кралюк П. Шестиднев, або Корона роду Острозького : роман. Київ : Ярославів Вал, 2010. 320 с. 